\title{
The Effect of Liberica Coffee on Liver Physiology and Histological Appearance of White Mice
}

\author{
Cindra Ayuning Kirana ${ }^{1}$, Syamsurizal ${ }^{2}$, Diah Tri Utami ${ }^{1, *}$ \\ ${ }^{1}$ Department of Pharmacy, Science and Technology Faculty, Universitas Jambi, Indonesia \\ ${ }^{2}$ Department of Chemistry education, Faculty of Teacher training and Education, Universitas Jambi, Indonesia
}

\begin{abstract}
Indonesia is one of the world's top coffee producing and exporting countries. Liberica coffee was one of the most widely cultivated types of coffee in Indonesia, especially in Tanjung Jabung Barat Jambi Province. Liberica coffee known as the coffee with highest levels of caffeine if compared with Arabica and Robusta coffee but the research about Liberica coffee was still very little if compared to the other two types of coffee. In the previous research, caffeine shown to be increasing alanine aminotransferase enzyme. Otherwise, coffee also contain chlorogenic acid which is a potent antioxidant and play a role in the protection of liver. The aim of this study are to investigate the effect of dark roasted Liberica coffee consumption on liver histological appearance, macroscopic anatomy and physiological function (serum glutamic-pyruvic transaminase (SGPT) level). This was an experimental study with posttest only control group design, using 45 male white mice and divided into 4 groups: control (with no coffee treatment), P1, P2 and P3 which were given coffee treatment consecutively 8000 ppm; 10.000 ppm and 12.000 ppm for 28 days. The result showed that liver histological damage level associated with the extent coffee intake. Although, the damage shown is still in a low level and has no impact in increasing SGPT level.
\end{abstract}

Keywords : Liberica coffee, Liver, Histological appearance, SGPT level

\section{INTRODUCTION}

Indonesia is the third country of the largest coffee producer in the world after Brazil and Vietnam (Siti, et al., 2015). There are many types of coffee on the market but in general, the biggest is the type of Arabica coffee (Coffea arabica), Liberica coffee (Coffea liberica) and Robusta coffee (Coffea canephora) (Najiyati, 2009). Between this three types of coffee, Liberica coffee has a unique characteristic that can be found on peatland especially in Tanjung Jabung Barat of Jambi Province. Liberica coffee has higher levels of caffeine compared to Robusta coffee and Arabica coffee (Hermanto, 2007). The caffeine levels of Arabica and Robusta coffee are $1.17 \%$ and $1.99 \%$, while Liberica coffee caffeine level is $2.19 \%$ (Aditya, 2015) which this compound is metabolized in the liver by cytochrome P450 oxidase enzymes.

From several studies, presented that coffee has the potential that can cause cancer and liver disease characterized by the increase of alanine

Submitted: September 13, 2018

Revised: October 2, 2018

Accepted: October 3, 2018

*Corresponding author: diahtriutami@unja.ac.id 
aminotransferase enzyme which is a sign of hepatocyte damage. Roasted coffee at high temperatures (dark roasted) is reported to have favorable characteristics of the community. According to research conducted by Purnamayanti, et al. (2017) on panelists, it was presented that panelists prefer the aroma, taste and color of steeped Arabica coffee roasted at $235^{\circ} \mathrm{C}$ compared to temperatures of 220 and 250 . In addition, roasted coffee at high temperatures causes the emergence of new compounds that are harmful to health. According to Summa, et al. (2006), acrylamide and melanoidin are the results of Maiilard reactions that are formed during the process of roasting coffee especially in the temperature range $210-250^{\circ} \mathrm{C}$. Acrylamide compounds presented by Mahmood, et al. (2015), may provide a histological change in hepatic appearance when compared with the control group.

On the other hand, according to Jhonston, et al. (2003), coffee has some strong polyphenol compounds such as chlorogenic acid that can prevent tissue damage from free radicals by reducing or eliminating reactive oxygen species so that regeneration of injured liver cells can take place.

The research about the effect of Liberica coffee on hepatic organ histology has not been done. The effect of coffee consumption on hepatic organ also remains a controversy, especially in roasting coffee at high temperatures (above $210^{\circ} \mathrm{C}$ ). Some researches haves been done, but only in Arabica and Robusta coffee. So it is important to conduct a research on the effect of Liberica coffee to the liver.

\section{MATERIALS AND METHODS}

\section{Preparation of Samples and Treatments}

The coffee powder used was the coffee powder from Liberica coffee beans. The coffee powder was weighed according to the treatment dose and dissolved in hot water with the specified volume. The coffee solution was cooled before it is administered to the test animal on a per-oral basis using a sonde needle.

Test animals were divided into 4 groups, each group consisting of 12 male mice. All mice were adapted for 2 weeks, given the same standard feed and drink ad libitum. The first group was the control group which was given only standard feed and water and did not get the treatment of coffee, while the next group (P1, P2 and P3) were treated with a dose of $8000 \mathrm{ppm}, 10,000 \mathrm{ppm}$ and $12.000 \mathrm{ppm}$ per day.

\section{Observation of Hepatic Macroscopic Morphology}

The test animals were sacrificed and the livers were taken to observe the hepatic color, surface, weight and volume. Hepatic weight was measured using an analytical balance. Hepatic volume was measured by putting the liver into a measuring cup that has been filled with water and assessing the volume difference before and after inserted liver in water (Maharani, 2007).

\section{Preparation of Histological Slide}

Preparation of histological slide was performed by fixation using formalin buffer, dehydration using stratified alcohols with concentrations of $70 \%, 80 \%, 90 \%, 96 \%$ and $100 \%$. The organs were removed from the alcohol by using xylol and paraffin. The organ was then infiltrated using paraffin to make paraffin block. The paraffin block was slashed (Sectioning) using Rotary microtome thickness of 3-4 $\mu \mathrm{m}$. The sectioned liver was dried vertically, then placed on a glass object, then the section are stained using a Haematoxilin-Eosin dye and observed under a microscope (Muntiha, 2001). The histology was observed on the 5 fields with magnification $10 \mathrm{x} 40$.

On each slide the average value was calculated by multiplying number of cells according to their category with the value used (Table 1). The target read is a change in the liver's histological structure of the mice. 
Indonesian Journal of Cancer Chemoprevention, October 2018

ISSN: 2088-0197

e-ISSN: 2355-8989

Table 1. Evaluation criteria for degenerated cells.

\begin{tabular}{lc}
\hline \multicolumn{1}{c}{ Degeneration Type } & Roenijk Grade \\
\hline Normal cell & 1 \\
Parenchymatous degeneration & 2 \\
Hidropic degeneration & 3 \\
Necrosis (pyknosis, karyorrhexis, karyolysis) & 4 \\
\hline
\end{tabular}

Description: Grade I represents normal findings or mild fatty changes; grade II includes severe spotty hepatocellular necrosis; grade III is a mild portal fibrosis, with or without fibrotic septa extending into the lobule; grade IV is true cirrhosis with loss of normal architecture, fibrosis and nodular regeneration.

\section{Measurement of Serum Glutamic-pyruvic Transaminase (SGPT) Levels on Treated Mice}

On the $28^{\text {th }}$ day, the blood was taken through a jugular vein (a blood vessel in the neck). The blood sample was inserted into the test tube without anticoagulation in order to get the serum. Using SGPT cuvette I kit as the blanks, which was added with $100 \mathrm{~mL}$ of distilled water and 1000 $\mu \mathrm{L}$ of reagent I. After mixing, the samples were incubated for 5 minutes at $37^{\circ} \mathrm{C}$. Each cuvette were with added $250 \mathrm{~mL}$ of reagent II. After mixing and incubating for 1 minute at the same temperature, Optical density (OD) was determined with the spectrophotometer at a wavelength of $365 \mathrm{~nm}$. OD reading was repeated 3 times with 1 minute interval. Delta absorbent ( $\Delta$ Absorbance)/min was then multiplied by conversion factor of 1768 to obtain SGPT (Dialab, 2006).

\section{RESULTS}

\section{Macroscopic Anatomy of Mice Liver}

On the analysis of mice liver volume, it was found that covariate (body weight) did not affect hepatic volume $(p=0.08>0.05)$. The same thing was observed in the analysis of hepatic mice weight where $p$-value $0.490>0.05$. This shows that the effect on test results is caused by group treatment and is not influenced by covariate variables (body weight of mice). Figure 1 showed volume increments and hepatic organ weight of mice which are treated with liberica coffee for 28 days.

Based on Ancova test after 28 days of Liberica coffee it was found that there was no significant difference in mice hepatic volume due to the giving of group of coffee dose of Liberica for 28 days. In line with this, the analysis on the

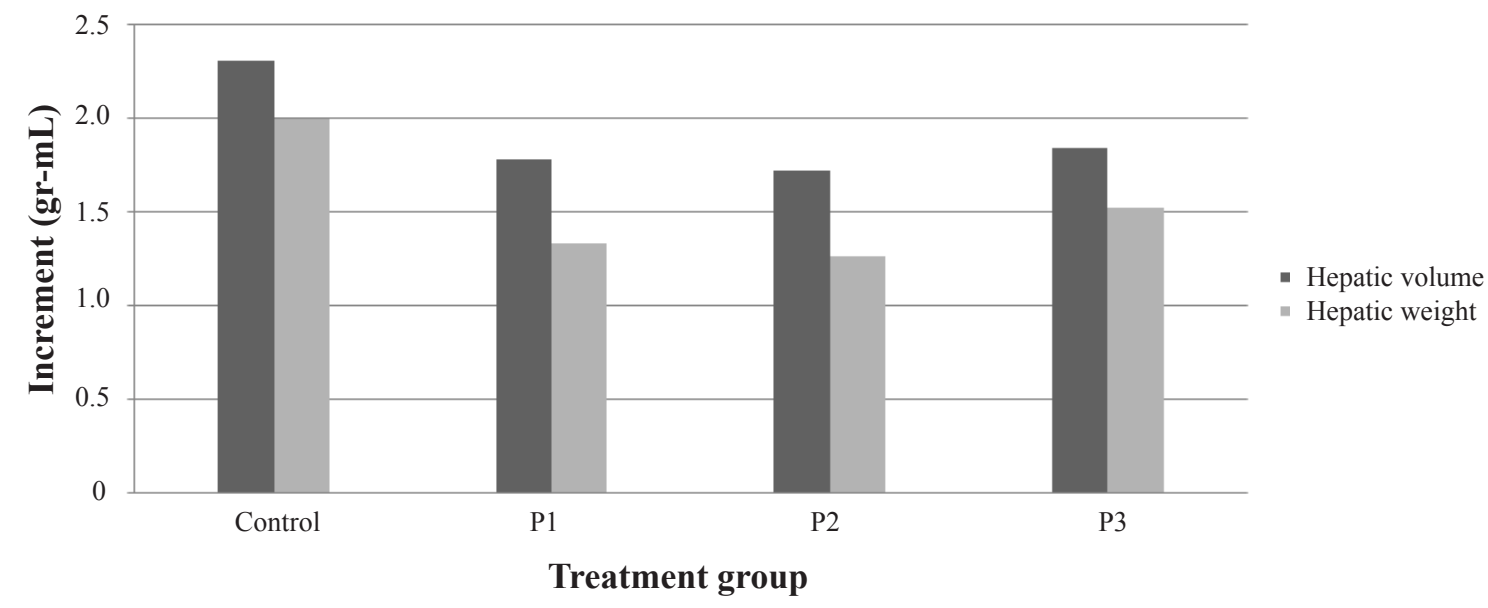

Figure 1. The average bar chart of volume increments and hepatic organ weight of mice treated with liberica coffee for 28 days. The increment was determined by subtracting the liver volume and weight after and before treatment. 
treatment of hepatic organ weight of mice was also not significant. Based on the statistical results it is known that the treatment of liberica coffee for 28 days at doses of 8,000 ppm, $10.00 \mathrm{ppm}$ and 12,000 ppm did not affect the volume and hepatic weight of mice.

\section{External Color and Surface of the Mice Liver}

In the overall hepatic surface of controlled group (not experiencing fibrosis) as well as in the overall liver organ color observed red brick with a flat color spread and the discovery of no white spots. Furthermore, in the group of P1 the color of mice liver are found almost entirely pale red although not yet observed the presence of spots on the organs. While in the P2 group there are several pale red organs were observed and there is presence of organs with fibrosis on the surface which is characterized by the appearance of white spots and organ colors tend to be bluish red. Overall, the liver organ in the P2 group showed some signs of damage with the appearance of even slightly white spots. In the P3 group treated with the highest doses of coffee was observed almost entirely organ were have pale red color and there were many organs with white spots even on hepatic surface observation, no discovery of fibrosis-acquired organs (Figure 2).

\section{SGPT Levels of Mice After Treatment}

SGPT levels of mice treated with liberica coffee for 28 days were analyzed using enzymatic methods (Figure 3). The results showed that the average SGPT level in the control group was 2.19 $\mathrm{U} / \mathrm{L}$, while the SGPT levels of the treatment group increased with increasing dose.

Based on Anova test, it was found that there was no significant difference in SGPT levels of mice due to the giving of a group of coffee dose of liberica for 28 days with control group to $p$-value $0.205>0.05$. The consumption of Liberica coffee for 28 days did not affect the levels of SGPT mice. This is suspected because the damage that occurs in the liver tend to be mild. This damage is reversible so it does not affect the levels of alanine transaminase (ALT) enzymes in the liver.

\section{Histology of Liver Mice After Liberation of Coffee}

The results observed in hepatic histology preparat of control group mice, hepatocyte cells appear normal and arranged radial around the central vein associated with the sinusoid space (Figure 4A). In the $\mathrm{P} 1$ group of hepatic cells begin mild degeneration (Figure 4B). In P2 and P3 groups the degeneration rate was found to be higher than that in $\mathrm{P} 1$ and found some signs of mild necrosis (Figure 4C).
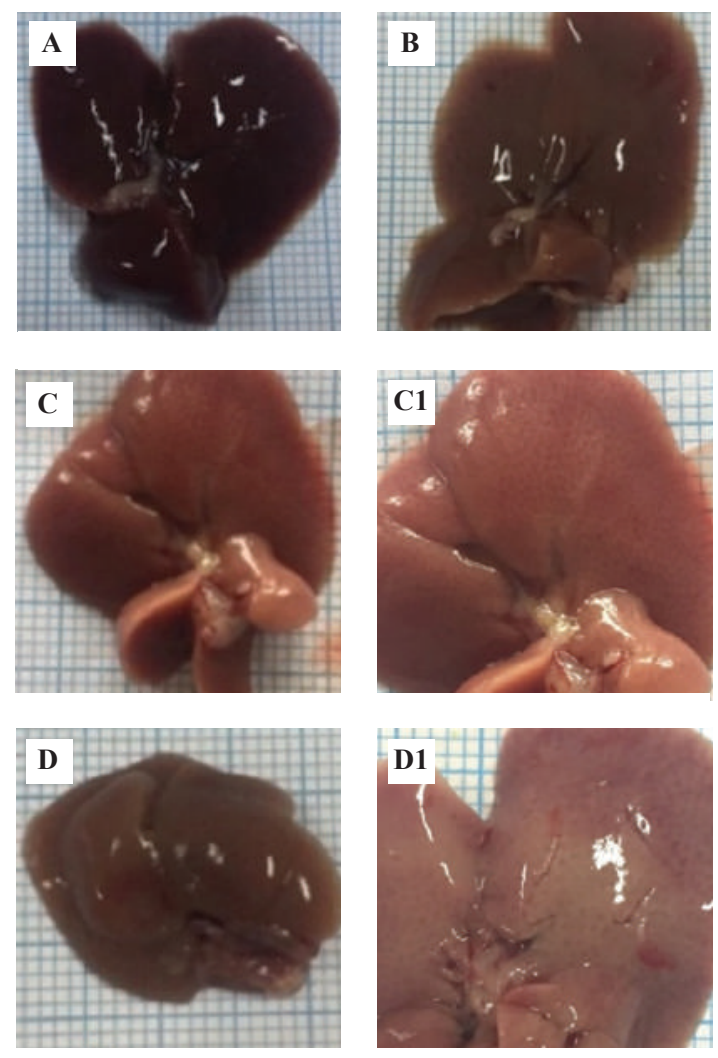

Figure 2. The color and liver surface of mice fed with Liberica coffee for 28 days. A: control group; B: group P1 (8000 ppm); C: group P2 (10,000 ppm) C1: white spots found in organ of group P2 mice D: group P3 (12,000 ppm); D1: white spots found in P3 group mice. 


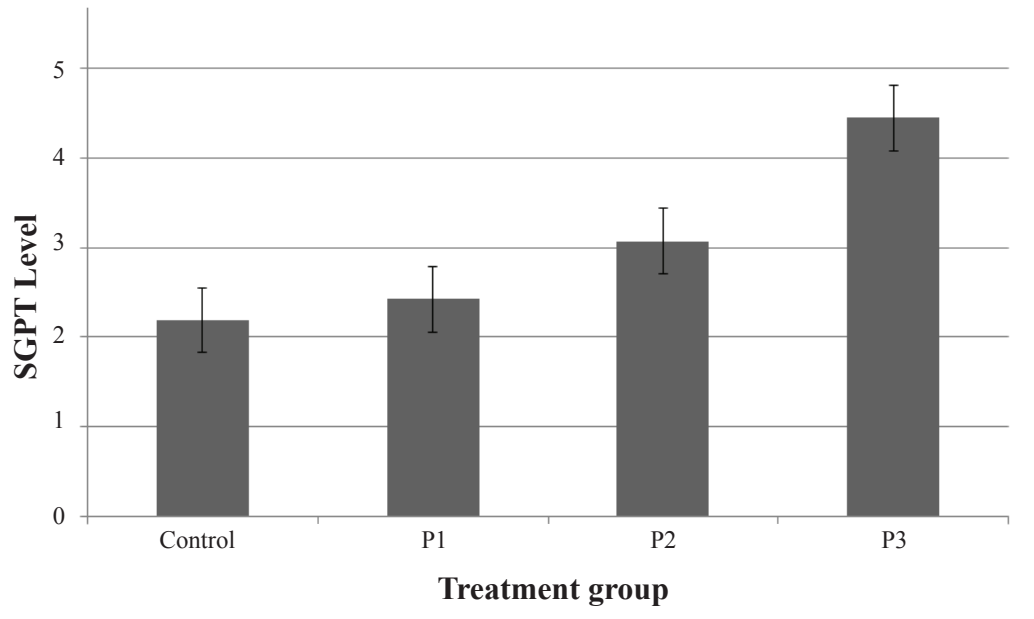

Figure 3. SGPT levels of mice treated with Liberica coffee for 28 days.
In the observation of hepatic cell histology, the mean hepatocyte cell score increased with the increasing dosage (Table 2). This is aligned with the concept of the relationship between concentration and response that is in a certain dose range, the concentration of the drug on the receptor can cause therapeutic effects, but can also cause toxic effects. Where is the higher concentration, the greater the response (the response of therapy and toxic response).
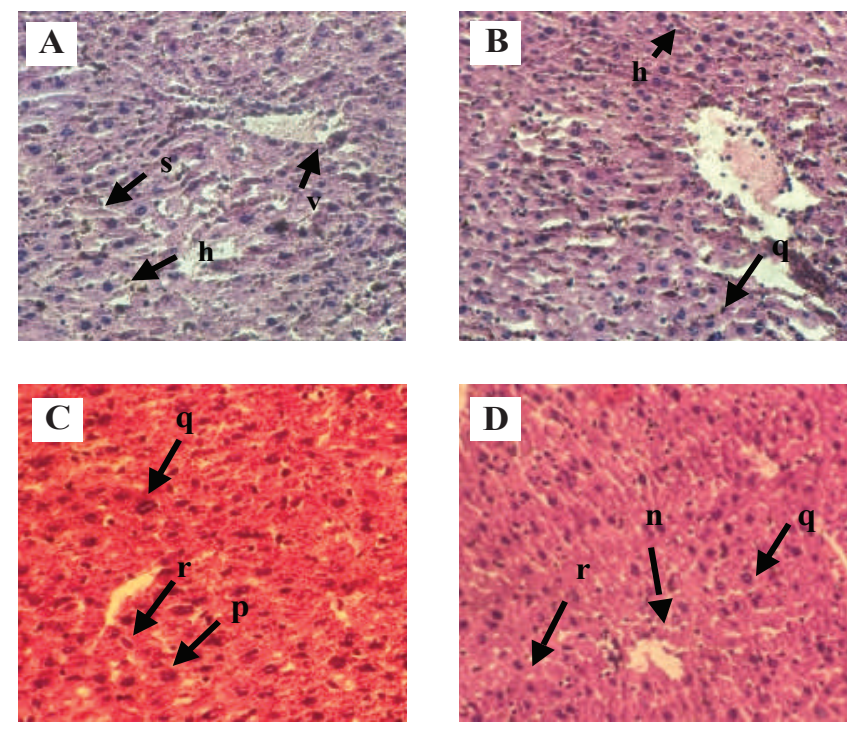

Coffee entering through the gastrointestinal tract will experience early metabolism in the liver because the liver is the main metabolic site that will detoxify and eliminate all endogenous or exogenous toxins. The detoxification process that exceeds the hepatic capacity will force the liver to work harder and ultimately result in damage to liver cells, which can be seen on the liver surface, i.e., miller necrosis and the appearance of white bumps (Mark, 2004).

Figure 4. Histologic hepatic preparation photos with magnification $40 \times 10$. A: control, B: Group P1 C: Group P2, D: P groups P3. Normal hepatic cell criteria are indicated by the whole arrow and the degenerate liver cell criteria are indicated by dashed arrows. $\mathrm{s}=$ sinusoid; $\mathrm{h}=$ normal hepatocytes; $v$ = central vein; $p=$ parenchymatous degeneration; $q=$ hydropic degeneration; $r=$ piknosis (wrinkled, dense, dark-colored cell nucleus); $\mathrm{n}=$ empty space due to necrosis. 
Table 5. Chemoprevention Effects of Pinostrobin.

Kirana, et al, 2018

Indones. J. Cancer Chemoprevent., 9(3), 152-159

Table 2. Score level in histological images of hepatic cells.

\begin{tabular}{|c|c|c|c|c|c|c|}
\hline \multirow{2}{*}{ Group } & \multicolumn{4}{|c|}{ Degeneration Score } & \multirow{2}{*}{$\begin{array}{c}\text { Repeat } \\
\text { Rate }\end{array}$} & \multirow{2}{*}{ Score-N } \\
\hline & I & II & III & IV & & \\
\hline Control & 75.8 & 58.4 & 55.6 & 54.2 & 61 & $1.35^{\mathrm{a}}$ \\
\hline $\mathrm{P} 1$ & 119.6 & 84.8 & 77.8 & 82.2 & 91.1 & $1.67^{\mathrm{ab}}$ \\
\hline $\mathrm{P} 2$ & 138.2 & 122.2 & 116.4 & 95.8 & 118.15 & $1.92^{\mathrm{abc}}$ \\
\hline P3 & 152.4 & 159 & 124.4 & 129 & 141.2 & $2.02^{\mathrm{ac}}$ \\
\hline
\end{tabular}

The result of microscopic study showed that the consumption of Liberica coffee with dosage above $8000 \mathrm{ppm}$, histopathology of liver is significantly different at significant level 0.05 compared with not consuming the coffee. Histological changes that occur include parenchymatous degeneration, hydropic degeneration and necrosis. Parenchymatous degeneration is the mildest degeneration, swelling and cytoplasmic turbidity due to the emergence of granules in the cytoplasm due to protein precipitate. The affected cells can not eliminate the water so it is buried in the cell so that the cell swells. Hydropic degeneration is a more severe degree of damage, in this degeneration of visible vacuoles containing water in the cytoplasm that does not contain fat or glycogen, its cytoplasm becomes pale and swollen by a pile of fluid (Fajariyah, 2010).

\section{DISCUSSION}

The treatment of coffee liberica on 28 days did not affect the macroscopic anatomy and SGPT level of male mice liver, but showing some change in color, external surface and histological appearance when compare to the controlled group. The damage to this liver cell can be due to the content of caffeine in coffee. According to Daswin, et al., (2013), cell damage can also occur through immune mechanisms, because in coffee there is caffeine has a molecule similar to adenine and bind to the adenosine receptor, especially in A2A adenosine receptor which then releases the mechanism of suppression immunity, proinflammatory cytokines, and lead to acute cell damage due to T cells and myelocyte cells.

Macroscopic changes of hepatic organ of mice treated with Liberica coffee for 28 days are one of the symptoms of mice hepatic damage. The damage may include reversible (degenerative) or irreversible (necrotizing) changes. In accordance with the statement Sudiono, et al. (2001), the macroscopically damaged tissue looks more pale and transparent when compared with normal surrounding tissue.

Roasted Liberica coffee at a temperature of $230^{\circ} \mathrm{C}$ causes some compound content in coffee to change, either the compound content that gives both beneficial and adverse effects. According to a study conducted by Edvan, et al. (2016) on Robusta coffee species, the process of roasting at temperatures above $210^{\circ} \mathrm{C}$ can cause a decrease in caffeine levels by $43.40 \%$. Decrease in caffeine levels will be aligned with the decrease of adverse effects caused by coffee consumption, so the likelihood of damage to liver organ may be reduced. In addition, organ damage at low levels and reversible include degeneration, can not affect macroscopic morphology of liver organ due to proliferation ability owned by hepatocyte cells.

The mild and reversible liver injury (degeneration) did not affect the levels of 
ALT because the liver's ability to regenerate their cells. Levels of these enzymes do not correlate well with the extent of liver damage or the prognosis. This is consistent with the statement of Asikin (2001), an increase in levels of alanine aminotransferase may occur due to increased levels of oxidants generated in gluconeogenesis during stress, along with the body's ability to do a protection mechanism through the establishment antioxidants. The antioxidant role is to prevent the formation of oxidants, modify oxidant compounds into other compounds that are not toxic to the body, and repair the damage. Thus, appropriate ALT (SGPT) levels can not be used to determine the degree of liver damage (Kee, 2007).

\section{CONCLUSION}

The consumption of Liberica coffee for 28 present a difference to macroscopic morphology in the form of color, hepatic surface and histological appearance compared with animals that were not treated (control), but no changes in hepatic weights, hepatic volume and levels of SGPT mice. The histological score of mice hepatic was gave a different images of histology hepatic damage compared to the group that was not treated by liberal coffee (control) but the damage that occurs due to the consumption of liberica coffee is at a low level so that changes only occur on macroscopic images and histological appearance. The damage was not affected the overall liver function so as not to raise the levels of SGPT mice that were given liberica coffee.

\section{ACKNOWLEDGEMENT}

The authors would like to thank the Institute for Research and Community Service of the Science and Technology Faculty of Universitas Jambi and Ministry of Research, Technology and Higher Education of the
Republic of Indonesia (RISTEK DIKTI RI)for the support in this study.

\section{REFERENCES}

Aditya, I.W., Nocianitri, K.A. and Yusasrini, N.L.A., 2015, Kajian Kandungan Kafein Kopi Bubuk, Nilai pH dan Karakteristik Aroma dan Rasa Seduhan Kopi Jantan (Pea Berry Coffee) dan Betina (Flat Beans Coffee) Jenis Arabika dan Robusta, Jurnal Fakultas Teknologi Pangan, 5(1), 1-12.

Ananda, Sipahutar, H. and Nugrahalia, M., 2014, Daya Fertilitas Mencit (Mus musculus) Betina Pasca Pemberian Air Seduhan Kopi Peroral, Proceeding, Padang: Seminar Nasional Biodiversitas dan Ekologi Tropika Indonesia, pp.6-9.

Asikin, N., 2001, Antioksidan Endogen dan Penilaian Status Oksidan, Jakarta: Repository Fakultas Kedokteran Universitas Indonesia.

Bhara, M., 2004, Pengaruh Pemberian Kopi Dosis Bertingkat Per Oral 30 Hari Terhadap Gambaran Histologi Hepar Tikus Wistar, Thesis, Semarang: FK Universitas Diponegoro.

Boekschoten, M.V., Schouten, E.G., Katan, M.B, 2004, Coffee Bean Extract Rich and Poor in Kahweol Both Rise to Elevation of Liver Enzyms in Healthy Volunters, Nutr. J., 3, 7.

Daswin, N. and Samosir, N.E., 2013, Pengaruh Kafein Terhadap Kualitas Tidur Mahasiswa Fakultas Kedokteran Universitas Sumatera Utara. E-Jurnal FK-USU, 1(1), 1341.

Dialab, 2006, Liquid Reagents of GOT (AST), Austria: DIALAB Production von chemish-technishen.

Fajariyah, S., Utami, E.T. and Arisandi, Y., 2010, Efek Pemberian Estrogen Sintetis (Diethylstillbestrol) Terhadap Struktur Hepar dan Kadar SGOT dan SGPT pada Mencit (Mus musculus) Betina Strain Bal/C, J. Ilmu Dasar, 11(1), 76-82.

Handajani, F., 2008, Pengaruh Pemberian Ekstrak Buah Merah (Pandanus conoideus L) pada Kadar SGOT dan SGPT Tikus Putih yang Diinduksi Parasetamol Dosis Tinggi Tunggal, Surabaya: Universitas Airlangga.

Hermanto S., 2007, Kafein Senyawa Bermanfaat atau Beracunkah, Jakarta: [no publisher]. 
Johnston K.L., Clifford M.N., Knight S. and Kuhnert N., 2003, Hierarchical Scheme for LC-MSn Identification of Chlorogenic Acids, J. Agric. Food Chem., 51(10), 2900-2911.

Kee, J.L., 2007, Pedoman Pemeriksaan Laboratorium dan Diagnostik, 6th Ed, Jakarta: Penerbit Buku Kedokteran EGC.

Kreicbergs, V., Dimins, F., Mikelsone, V. and Cinkmanis, I., 2011, Biologically Active Compounds in Roasted Coffee, Proceeding, Latvia: Foodbalt 2011, pp.110-115.

Lee, K.A., Chae, J.I. and Shim, J.H., 2012, Natural Diterpenes from Coffee, Cafestol and Kahweol Induce Apoptosis through Regulation of Specificity Protein 1 Expression in Human Malignant Pleural Mesothelioma, J. Biomed. Sci., 19, 60. doi: 10.1186/1423-0127-19-60.

Li, S.Y., Chang, C.Q., Ma, F.Y. and Yu, C.L., 2009, Modulating Effects of Chlorogenic Acid on Lipids and Glucose Metabolism and Expression of Hepatic Peroxisome Proliferator-Activated Receptor-Alpha in Golden Hamsters Fed on High Fat Diet, Biomed. Environ. Sci., 22(2), 122-9.

Maharani, P., 2007, Histopatologi Organ Hati dan Mata Pada Tikus Penderita Diabetes Mellitus Eksperimental, Essay, Bogor: Fakultas Kedokteran Hewan Institut Pertanian Bogor.

Muntiha, M., 2001, Teknik Pembuatan Prepatar Histopatologi dari Jaringan Hewan dengan Pewarnaan Haematoksilin dan Eosin (H\&E), Proceeding, Bogor: Temu Teknis Fungsional Non Peneliti, pp.156-163.

Murase, T., Misawa, K., Minegishi, Y., Aoki, M., Ominami, H., Suzuki, Y., Shibuya, Y., et al., 2011, Coffee Polyphenols Suppress Diet-Induced Body Fat Accumulation by Downregulating SREBP-1C and Related Molecules in C57BL/6J Mice, Am. J. Physiol. Endocrinol. Metab., 300(1), E122-E133.

Nagao, T., Ochiai, R., Watanabe, T., Kataoka, K., Komikado, M., Tokimitsu, I., et al., 2009, Visceral Fat-reducing Effect of Continuous
Coffe Beverage Consumption in Obese Subjects, Japan. Pharmacol.Ther., 37(3), 33-44.

Najiyati, S., and Danarti, 2009, Kopi: Budidaya dan Penanganan Lepas Panen, Jakarta: Penebar Swadaya.

Narita, Y. and Inouye, K.J., 2009, Kinetic Analysis and Mechanism on the Inhibition of Chlorogenic Acid and Its Components Against Porcine Pancreas Alpha-Amylase Isozymes I and II, J. Agric. Food Chem., 57(19), 18-25.

Ong, K.W., Hsu, A. and Tan, B.K., 2012, Chlorogenic Acid Stimulates Glucose Transport in Skeletal Muscle Via APMK Activation: A Contributor to the Beneficial Effects of Coffee on Diabetes, PLOS One, 7(3), e32718.

Ridwansyah, 2003, Pengolahan Kopi, Medan: Departemen Teknologi Pertanian, Fakultas Pertanian, Universitas Sumatera Utara.

Riswanto, A.T., 2009, Tinjauan Klinis Hasil Pemeriksaan Laboratorium, 11th Ed, Jakarta: Penerbit Buku Kedokteran EGC.

Robbins, S.L. and Kumar, V. 2001, Buku Ajar Patologi I (Basic Pathology Part II), 4th Ed, Jakarta: Penerbit Buku Kedokteran EGC.

Shimoda, H., Seki, E. and Aitani, M., 2006, Inhibitory Effect of Green Coffee Bean Extract on Fat Accumulation and Body Weight Gain in Mice, BMC Complement. Altern. Med., 6, 1-9. doi: 10.1186/1472-6882-6-9.

Siti, K., Laraswati, M. and Zatul, S., 2015, Analisis Konflik Laten Jepang-Cina. Peluang, Hambatan dan Kebijakan Ekspor Kopi Indonesia ke Pasar Amerika Serikat, Jurnal Ilmu Hubungan Internasional, 3(1), 758-760.

Sudiono, S., Hidayat. S., Rusmilah, S. and Soemartono, S., 2001, Deteksi Molekuler dan Uji Kisaran Inang Virus Gemini Asal Tanaman Tomat, Proceeding, Bogor: Konggres Nasional XVI, PFI, ISBN 97995938-1-6, pp.210-216.

Wresdiyati, T., 2006, Profil Imunohistokimia Superoksida Dismutasi (SOD) Pada Jaringan Hati Tikus dengan Kondisi Hiperkolesterolemia, Hayati, 13(3), 85-89. 